\title{
Legers syn på helsevurdering for førerkort
}

\begin{abstract}
Sammendrag
Bakgrunn. Vurdering av helse og utfylling av helseattest for førekort oppleves av mange leger som en vanskelig oppgave. Vi ønsket å innhente kunnskap om hva som oppleves som spesielt vanskelig, og hvilke tiltak legene $ø$ nsker seg for at oppgaven skal bli lettere å utføre.
\end{abstract}

Materiale og metode. Et spørreskjema ble utviklet på grunnlag av forfatternes egen erfaring innen feltet. Skjemaet inneholdt 13 spørsmål, to åpne og 11 lukkede, med mulighet for utdypning for fire av spørsmålene. Spørreskjemaet ble sendt til et tilfeldig utvalg av allmennleger ( $n=680$ ) og spesialister i geriatri, nevrologi, psykiatri og fysikalsk medisin og rehabilitering ( $n=493$ ). Det ble foretatt én purring. Svarene på de åpne spørsmålene ble kategorisert. Frekvensanalyser ble gjennomført.

Resultater. $52 \%$ av allmennlegene og $55 \%$ av spesialistene besvarte spørreskjemaet. Kognitiv svikt, høy alder og rus- og alkoholproblemer ble angitt av allmennleger som det vanskeligste å vurdere i forbindelse med førerkortattester, mens spesialistgruppen oppga at pasienter med rus- og alkoholproblemer, psykiatrisk sykdom og legemiddelbruk var vanskeligst. Legene var ikke tilfreds med dagens tilbud om vurderingsbistand og etterspurte et trafikkmedisinsk senter der enkeltpasienter kan vurderes.

Fortolkning. Vurdering av helse for førerkort oppleves som vanskelig av mange leger. Mer spesifikke retningslinjer og et trafikkmedisinsk senter kan bistå leger i denne vanskelige og viktige oppgaven.

\author{
Anne Brækhus \\ anne.brakhus@ulleval.no \\ Nevrologisk avdeling \\ og \\ Geriatrisk avdeling \\ Oslo universitetssykehus, Ullevål \\ 0407 Oslo \\ Torgeir Bruun Wyller \\ Geriatrisk avdeling \\ Oslo universitetssykehus, Ullevål \\ og \\ Universitetet i Oslo
}

\section{Knut Engedal}

Nasjonalt kompetansesenter for aldring og helse Oslo universitetssykehus, Ullevål og

Universitetet i Oslo

Bilkjøring stiller store krav til kognitive, sensoriske og motoriske funksjoner. Mange sykdommer som for eksempel demens, psykiatrisk sykdom, nedsatt syn og sekvele etter hjerneslag, innebærer svikt i disse funksjonene, og kan medføre risikofylt kjøring. Tidligere studier dokumenterer kun en lett til moderat forhøyet ulykkesrisiko for disse pasientgruppene (1). Det er likevel ingen tvil om at utfordringene for legene er store pga. det store antallet pasienter som må vurderes med tanke på om de er helsemessig skikket til å beholde førerkortet. Det finnes i dag om lag 70000 personer med demens, i 2040 vil det være om lag 135000 (2). Andre sykdommer som vil vise en tilsvarende stor økning de neste tiårene er hjerneslag (3). Det finnes få kunnskapsbaserte retningslinjer for når bilkjøring er for risikabelt eller ulykkesrisikoen for høy for syke personer.

Leger er sentrale ved vurdering av helse for førerkort. De skal fylle ut attester både for første gangs førerkort (dersom egenattest ikke er tilstrekkelig), ved førerkortklasser for tyngre kjøretøy og kjøreseddel, for bilførere 70 år og eldre, samt vedlegge helseopplysninger der pasienten søker om dispensasjon fra helsekravene. Når helsemessige krav for å inneha førerkort ikke er oppfylt, har legene meldeplikt til myndighetene. Sosial- og helsedirektoratet (nå Helsedirektoratet) har utarbeidet retningslinjer for vurdering av helse for førerkort, men det kan likevel være vanskelig å foreta en korrekt vurdering og å tolke resultatene av gjennomførte undersøkelser (4).

Fra ulike hold kritiseres leger med jevne mellomrom for at de gjør en for dårlig jobb ved førerkortvurderinger $(5,6)$. Tidligere studier og egen erfaring tyder på at de medisinske vurderingene ofte oppleves som vanskelige av legene, regelverket tolkes ulikt, og at dobbeltrollen som pasientens «advokat» og «dommer» kan medvirke til at leger i noen grad unnlater å ta fatt i disse problemstillingene (7-9).

I de nærmeste 20 årene vil vi i Norge få en betydelig økning i antallet eldre bilister med kroniske sykdommer og mulig svikt i funksjoner av betydning for kjøreferdigheter. Det er ikke usannsynlig at morgendagens bilister vil ønske en grundigere helsemessig vurdering enn det som i mange tilfeller gis i dag. Neste generasjon eldre vil neppe like lett akseptere legers skjønnsmessige vurdering dersom den ikke bygger på forskningsbasert kunnskap. Det er ønskelig med mer kunnskap om hvilke helse- og aldersmessige forhold leger synes er spesielt vanskelige å vurdere ved utstedelse av helseattest for førerkort.

Hensikten med denne spørreundersøkelsen var å innhente mer presis informasjon om hva leger opplever som vanskelig i denne sammenhengen og hvilken bistand de ønsker seg for å gjøre en bedre jobb.

\section{Materiale og metode}

Vi utarbeidet to spørreskjemaer, ett til allmennleger og ett til spesialister. De to skjemaene var like bortsett fra ett ekstra spørsmål til allmennlegene om hvor mange førerkortattester til eldre bilførere de utsteder per år. For øvrig inneholdt skjemaene 13 spørsmål, to åpne og 11 lukkede, med mulighet for utdypning for fire av spørsmålene. I denne artikkelen presenteres svar på åtte av spørsmålene (ramme 1).

Spørreundersøkelsen ble gjennomført anonymt, og det ble foretatt én purring. Allmennlegeskjemaet ble sendt til et tilfeldig utvalg på 680 leger, som utgjør om lag $15 \%$ av Legeforeningens 4433 allmennlegemedlemmer. Legene ble trukket ut fra forenin-

\section{Hovedbudskap}

- Mange leger opplever vurdering av helse for førerkort som vanskelig

- Vurdering ved kognitiv svikt, rus-og alkoholmisbruk, psykiatrisk sykdom, høy alder og medikamentbruk er særlig vanskelig

- Et senter som kan vurdere enkeltpasienter er etterspurt 
Tabell 1 Legenes opplevelse av de vanskeligste pasientene og problemstillingene ved vurdering av helse for å inneha førerkort. Flere svar var mulig. De angitte prosenter er av totalt antall avgitte svar

\begin{tabular}{lcc} 
& $\begin{array}{c}\text { Allmennleger } \\
\text { (n=819 avgitte svar) }\end{array}$ & $\begin{array}{c}\text { Spesialister } \\
\text { (n= } 465 \text { avgitte svar) }\end{array}$ \\
\hline Kognitiv svikt & Antall (\%) & Antall (\%) \\
\hline Høy alder & $200(24)$ & $91(20)$ \\
\hline Legemiddelbruk & $169(21)$ & $42(9)$ \\
\hline Rus- og alkoholmisbruk & $125(15)$ & $33(7)$ \\
\hline Anfallslidelser & $57(7)$ & $56(12)$ \\
\hline Psykiatrisk sykdom & $48(6)$ & $52(11)$ \\
Sammensatt & $32(4)$ & $69(15)$ \\
Annet & $43(5)$ & $30(6)$ \\
\hline
\end{tabular}

gens medlemsdatabase. Spørreskjemaet til spesialister ble sendt til et tilfeldig utvalg innen de fire spesialitetene geriatri, fysikalsk medisin og rehabilitering, nevrologi og psykiatri, dvs. de spesialistgruppene som ofte behandler pasienter med sykdommer som kan berøre bilkjøring, i alt 493 leger. I purrebrevet ble det gitt følgende oppfordring: «Hvis du synes det er vanskelig å angi antall og prosenter, skriv gjerne fritt om dine erfaringer og problemer når det gjelder legers oppgaver og ansvar i forhold til helse og førerkort » SPSS versjon 15 for Windows ble brukt til lagring og frekvensanalyser.

\section{Resultater}

Etter én purring besvarte 348 allmennleger skjemaet, en svarprosent på 52. 14 skjemaer kom i retur ubesvart, hovedsakelig pga. feil adresse. Allmennlegenes gjennomsnittsalder var 47,9 år (SD 10,9 år), 208 (64\% av dem som oppga kjønn) var menn, mens 230 $(66 \%)$ var spesialister i allmennmedisin. Allmennlegene vurderte i gjennomsnitt 48 pasienter (spredning $0-300$ pasienter) for førerkort per år og anga $\mathrm{i}$ gjennomsnitt at 31 $(64 \%)$ av disse pasientene var 70 år eller mer.

Etter én purring svarte 270 av spesialistene, dvs. en svarprosent på 55. Spesialistenes gjennomsnittsalder var 52,7 år (SD 8,3 år). Spesialistgruppen besto av 85 nevrologer, 27 geriatere, 110 psykiatere og 29 spesialister $\mathrm{i}$ fysikalsk medisin og rehabilitering. 19 oppga ikke spesialitet. Spesialistene vurderte i gjennomsnitt 26 pasienter (spredning $0-500$ pasienter) for førerkort årlig.

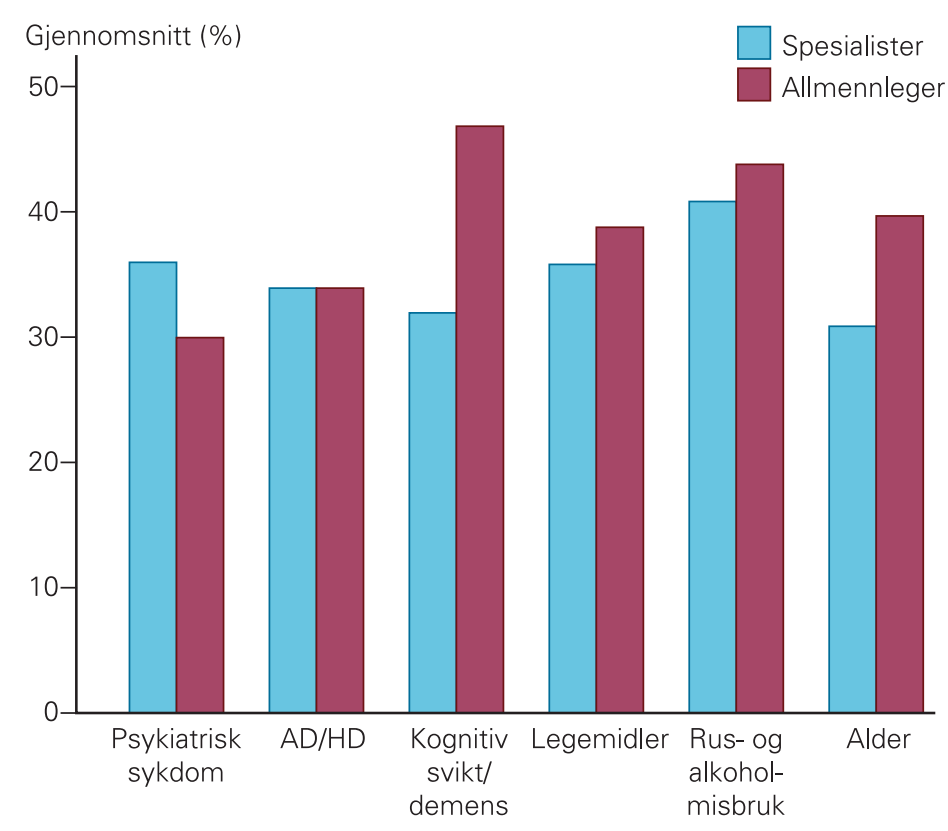

Pasientgrupper

Figur 1 Gjennomsnittstall for hvor stor andel av pasientene i hver gruppe som ble opplevd som vanskelige eller svært vanskelige å vurdere

På spørsmålet om hvilke pasienter og problemstillinger som er vanskeligst å håndtere, var det mulig å gi inntil tre svar. 319 (92\%) av allmennlegene ga minst ett svar på dette spørsmålet, og 819 svar ble gitt totalt. I alt $196(73 \%)$ av spesialistene ga minst ett svar, totalt 465 svar. Svarene ble kategorisert og viste at allmennpraktikere oppfattet ulike sider ved kognitiv reduksjon og høy alder som det vanskeligste, mens spesialistene anga faktorer knyttet til kognitiv svikt og psykiatrisk sykdom som det mest utfordrende (tab 1). Figur 1 viser gjennomsnittstall for hvor stor andel av pasientene i hver gruppe som ble opplevd som vanskelige eller svært vanskelige å vurdere.

På en skala hvor $1=$ liten arbeidsbelastning og $6=$ stor arbeidsbelastning, anga allmennlegene en gjennomsnittsskår på 3,4 (SD 1,1 skår) og spesialistene en gjennomsnittsskår på 3,1 (SD 1,4 skår) for sin arbeidsbelastning eller tidsbruk i forbindelse med førerkortvurderinger.

Vi spurte også om hvor vanskelig det er å vurdere om en person fortsatt skal få beholde førerkortet. På en skala fra 1 (i liten grad vanskelig arbeid) til 6 (i stor grad vanskelig arbeid) var gjennomsnittsskåren for allmennleger 3,8 (SD 1,1) og for spesialister 4,0 (SD 1,3).

Spørsmålet om legene opplevde spesielle problemstillinger knyttet til vurdering av eldre bilførere, ble besvart av $236(68 \%)$ av allmennlegene, hvorav 225 svarte ja, og av $119(44 \%)$ av spesialistene, hvorav 101 svarte ja. Et utvalg av legenes kommentarer til dette åpne spørsmålet er vist i ramme 2 .

Minst fornøyd med dagens bistand fra myndighetene var legene når det gjaldt kurs og annen opplæring, bare $16 \%$ av allmennlegene og $10 \%$ av spesialistene syntes tilbudet her er tilstrekkelig. Henholdsvis $20 \%$ og $15 \%$ syntes tilbudet om en instans som kan vurdere enkeltpasienter er tilstrekkelig. Mest fornøyd er de med skriftlige retningslinjer, $49 \%$ av allmennlegene og $39 \%$ av spesialistene synes at det er tilstrekkelig.

På spørsmål om hva som kan bidra til å gjøre dagens situasjon enklere å håndtere, svarte $52 \%$ av allmennlegene og $35 \%$ av spesialistene at det er «veldig viktig» med en instans med trafikkmedisinsk ekspertise som kan vurdere enkeltpasienter. På spørsmål om hvor fornøyde legene er med dagens bistand og om hvilke tilbud om bistand som ønskes fra myndighetene, var det mange ubesvarte og mange som svarte «vet ikke», 16-60\%.

\section{Diskusjon}

Vi fant at svært mange leger opplever helsevurdering for førerkort som vanskelig. Vurdering av pasienter med rus- og alkoholmisbruk, kognitiv svikt, psykiatrisk sykdom, legemiddelbruk og høy alder var særlig vanskelig.

Både allmennlegene og spesialistene mener at pasienter med kognitiv svikt utgjør en stor utfordring ved førerkortvurderinger. Pasientgruppen er stor, kognitiv svikt utvik- 


\section{Ramme 1}

\section{Spørreskjema}

1. Hvor mange førerkortvurderinger gjør du per år? Ta med alle type vurderinger; i forbindelse med akutt sykdom, kronisk sykdom, søknad om dispensasjon, helseattest for eldre bilførere, vurdering av yrkessjåfører, med mer. 1a. (kun til allmennleger). Hvor mange av disse gjelder helseattest for personer over 70 år?

2. Hvilke(n) pasientkategori(er)/problemstilling(er) opplever du som de(n) vanskeligste å håndtere? Angi de tre viktigste, f.eks bestemt sykdom, spesifikt symptom, medikamenter, sammensatte problemer, høy alder, eller andre forhold.

3. Ulike sykdommer/symptomer skal vurderes i forbindelse med bilkjøring. Angi hvor mange pasienter innenfor hver sykdomsgruppe du synes er vanskelig eller svært vanskelig å vurdere. (Bevissthetsforstyrrelse inkl epilepsi, psykiatrisk sykdom (schizofreni, depresjon), AD/HD, kogntiv svikt/demens, hjerneslag, Parkinsons sykdom, synsreduksjon/øyesykdommer, hjertelidelser, høyt medikamentforbruk, alkohol-/ rusmisbruk, førlighetssvekkelse (pareser/polynevropati), diabetes, «alderssvekkelse», annet/sammensatt).

4. Hvordan opplever du arbeidsbelastningen/tidsbruk ved vurdering av helse i forhold til fører-kort? Angi gjennomsnittlig arbeidsbelastning basert på de vurderingene du gjør. Skala 1-6.

5. Hvordan opplever du å skulle avgjøre om en person fortsatt skal kunne beholde førerkort? Angi gjennomsnittlig hvor vanskelig det er. Skala 1-6.

6. Er det spesielle problemstillinger/ vanskeligheter ved vurdering av eldre bilførere?

7. Mange opplever dagens ordning med vurdering av førerkort som utfordrende. Er dagens tilbud (retningslinjer, bistand og liknende) tilstrekkelig?

8. Hvis du svarte «ikke tilstrekkelig» på spørsmål 7, hvor viktig er et bedre tilbud for deg?

ler seg ofte langsomt, det finnes få gode vurderingsmetoder, kunnskapen om kognitiv svikt hos leger er i mange tilfeller mangelfull, og pasienten har ofte selv liten innsikt $i$ at kjøring kan være trafikkfarlig. En tilstrekkelig vurdering tar tid, noe som er lite forenlig med allmennlegenes og sykehuspoliklinikkenes stramme tidsskjema.

Det er utført mange studier om når i forløpet av en demenssykdom man ikke er egnet til å kjøre, men dette har i praksis vist seg vanskelig å vurdere (10). Dels skyldes det man- gel på en reell «gullstandard». Ideelt sett skulle det være en profil av kognitiv svikt og/eller en atferdsprofil som hyppig har vært assosiert med trafikkulykker, men slike profiler er ikke påvist. Man har heller ikke - til tross for mange studier - klart å påvise en enkel kognitiv test eller kombinasjon av kognitive tester som med sikkerhet kan predikere hvem som vil bestå en praktisk kjørevurdering (11). Dette bunner sannsynligvis $\mathrm{i}$ at de komplekse ferdighetene som kreves for å kjøre bil på en sikker måte, ikke så lett fanges opp av kognitive tester. Mange benytter praktisk kjørevurdering som «gullstandard», men dagens kjøretester er ikke standardisert, og det finnes ingen kunnskap om kjørevurderingers validitet som prediktor for ulykker.

Pasienter med «høy alder» ble angitt av allmennlegene som vanskelige å vurdere. Hva som oppfattes som høy alder, er usikkert. Biologisk aldring viser stor individuell variasjon, slik at «pasienter med høy alder» er en heterogen gruppe når det gjelder psykomotorisk tempo, syn, reaksjonstid og funksjon i muskel- og skjelettsystemet, forhold som er viktige for trygg bilkjøring. Noen er friske og fysisk og mentalt godt fungerende selv i langt fremskreden alder, mens andre har sykdommer som enkeltvis kan være forenlig med bilkjøring, men der kombinasjoner av ulike sykdommer gjør bilkjøring uforsvarlig. Noen gamle har udiagnostiserte lidelser, som f.eks. en begynnende demenssykdom, noe som ytterligere kompliserer bildet. Det finnes lite kunnskap om hva som predikerer trygg kjøring hos de aller eldste. De fleste studier er begrenset til personer med ulike sykdomstilstander, men der de aller eldste er utelatt $(12,13)$. Muligens er vurderingen av de svært gamle (over 85 år) med henblikk på kjøredyktighet en for vanskelig og omfattende oppgave for leger uten spesialkompetanse.

Psykiatrisk sykdom er et annet vanskelig område. Symptomer knyttet til persepsjon, informasjonsprosessering, konsentrasjon, hukommelse, psykomotorisk aktivitet, oppmerksomhet, impulskontroll, dømmekraft, problemløsning, vrangforestillinger og hallusinasjoner kan vanskeliggjøre bilkjøring. Det samme gjelder bruk av psykofarmaka. Sosial- og helsedirektoratets veileder er lite utfyllende på dette området og overlater i stor grad vurderingen til den enkelte leges skjønn (4). Problemstillinger som er vanskelige å vurdere er kombinasjoner av rusmisbruk og psykiatrisk sykdom, hypomane eller maniske tilstander med sjeldne episoder, remisjonsfase etter mani, eller psykoselidelser under behandling. Betydningen av psykisk sykdom for evnen til å kjøre bil på en sikker måte er lite studert, men enkelte studier dokumenterer høyere ulykkesforekomst hos denne pasientgruppen (14-16). I en undersøkelse av 208 pasienter ved en psykiatrisk poliklinikk, der de fleste led av angst og depressive lidelser, hadde $61 \%$ førerkort og kjørte daglig. På en kjøretest strøk 80 \% av pasien-

\section{Ramme 2}

\section{Eksempler på åpne svar vedrørende vurdering av eldre pasienter og helseattest for førerkort}

Manglende/liten innsikt

Svingende funksjon, evne til å kjøre varierer

- Fungerer godt på kontoret, men «klønete» i trafikken, burde ha prøvetime med kjørelærer

- Ofte ikke skarp grense mellom akseptabelt/uakseptabelt, snikende utvikling av symptomer

- Lett kognitiv svikt - generelt redusert psykomotrisk tempo uten spesifikke nevrologiske utfall

Nedsatt førlighet uten demens

Kort tid til å vurdere

Problemer med relasjonsetablering

Vanskelig å takle for pasienten, vanskelige samtaler, motstand hos pasient

Lett formell vurdering, litt tung emosjonell

- Får stor betydning for deres livskvalitet å miste førerkortet, slik at mye står på spill. Det kan slå ut i «ekstra skjerping» eller noen blir ekstra nervøse og det blir vanskelig å vurdere

- Ofte kan pasienter si at de har solgt bilen, og ikke kjørt på mange år. Men, det kan være usikkert om pasienten likevel kanskje har et førerkort liggende

- Mange eldre er mer avhengig av bilen til handling enn yngre fordi de fysisk ofte er dårlige. Mange har også sine problemer med angst og klarer ikke å forholde seg til offentlige transportmidler

Må intervjue pårørende

- Det største problemet er trusler fra enkeltpasienter

- Ofte er partner også avhengig av at bilførerne beholder førerkortet Påføres tap av frihet/verdighet

- Ja, det oppleves som en krenkelse av pasienten når du stiller spørsmål ved hans/hennes evne

- Ingen klare retningslinjer, flere får kjøre, kun noen få som blir tilfeldig undersøkt, hvor går grensen?

Den «gamle» med mer diffus svikt, sammensatte problemer og medikamenter/polyfarmasi

tene. I utvalget var ti yrkessjåfører, hvorav kun to besto kjøretesten (16).

Det var stor grad av overlapping mellom spørsmålet der legene ble bedt om å angi de tre vanskeligste områdene, og der de ble bedt om å angi hvor mange pasienter som var vanskelige eller svært vanskelige å vurdere innenfor oppgitte sykdomskategorier. Et unntak var $\mathrm{AD} / \mathrm{HD} .34 \%$ av pasientene $\mathrm{i}$ 
denne gruppen ble oppfattet som vanskelige eller svært vanskelige å vurdere, men det var relativt få av legene som oppga at de behandlet slike pasienter.

Misbruk av alkohol og andre rusmidler samt bruk av legemidler som reduserer oppmerksomheten, ble også ofte angitt som problematisk. Kjøring under legemiddelpåvirkning er et økende problem i Norge, og vi har manglende kunnskap om hvilke legemidler som er forenlig med trygg kjøring og hvilken dosering som er akseptabel $(17,18)$.

En stor del av legene vurderte dagens bistand fra helsemyndighetene som utilstrekkelige. At pasienter med spørsmål om førerkortvurdering ikke lenger er «rettighetspasienter» på sykehus, bidrar antakelig til at leger synes helsemyndighetene gjør for lite. Spesielt allmennlegene, men også en stor andel av spesialistene, mente at en instans med trafikkmedisinsk ekspertise som kan vurdere enkeltpasienter, ville være et viktig bidrag. På spørsmål om hvor fornøyde legene er med dagens bistand og om hvilken bistand som ønskes fra myndighetene var det mange ubesvarte og mange som svarte «vet ikke». Kan det bunne i at mange leger synes at oppgaven med å vurdere skikkethet for førerkort er lite forenlig med legerollen?

Kommentarer av mer generell karakter var nyttige for å tolke legenes svar.

Spørreskjemaet ble sendt til et tilfeldig utvalg av allmennleger og spesialister innen relevante spesialiteter, og svarprosenten tilsvarer den man har oppnådd i liknende undersøkelser $(7,19,20)$. Både gjennomsnittsalder og kjønnsfordeling blant allmennlegene $i$ vår studie tilsvarer gjennomsnittsalder og kjønnsfordeling blant norske allmennleger. $66 \%$ av respondentene var spesialister i allmennmedisin, i motsetning til $52 \%$ av alle allmennlegene i Norge. Spesialistenes gjennomsnittsalder tilsvarer om lag alderen i gruppen overordnet sykehuslege eller privatpraktiserende spesialist. Dette indikerer at de legene som besvarte spørreskjemaet kan være representative for gruppen leger som ble spurt om å delta.

\section{Konklusjon}

Leger oppfatter vurdering av helse ved utstedelse av helseattest for førerkort som vanskelig, særlig når det gjelder eldre personer. Bistanden som ytes fra myndighetene anses av mange som utilstrekkelig.

Helsedirektoratet har finansiert studien som denne artikkelen er basert på.

Oppgitte interessekonflikter: Ingen

\section{Litteratur}

1. Marshall SC. The role of reduced fitness to drive due to medical impairments in explaining crashes involving older drivers. Traffic Inj Prev 2008; 9 : $291-8$.

2. Helse- og omsorgsdepartementet. Demensplan 2015. «Den gode dagen». www.regjeringen.no/ Upload/HOD/Vedlegg/Planer/ Demensplan2015.pdf (7.3.2010).

3. Statens helsetilsyn. Scenario 2030. Sykdomsutvikling for eldre fram til 2030. Oslo: Statens helsetilsyn, 1999.

4. Regler og veiledning for utfylling av helseattest for førerkort m.v. IS-1437. Oslo: Sosial- og helsedirektoratet, 2007

5. Rapport fra tilsyn med leger og psykologers meldeplikt om førerkortkrav ved psykiatrien i Vestfold HF, Psykiatrisk fylkesavdeling (2008). www.helsetilsynet.no/templates/ Page 9870.aspx (19.12.2009)

6. Samuelsson SM. Läkares kontroll av körkortsfrå gor efter slaganfall. Tidsskr Nor Lægeforen 2005; 125: 2610-2.

7. Brækhus A, Engedal K. Mental impairment and driving liences for elderly people - a survey among
Norwegian general practitioners. Scand J Prim Health Care 1996: 14: 223-8.

8. Brodtkorb E, Bråthen G, Bovim G et al. Uenighet om epilepsi og bilkjøring. Tidsskr Nor Lægeforen 2004: 124: 1100-2.

9. Gulbrandsen P, Førde R, Aasland OG. Hvordan ha legen det som portvakt? Tidsskr Nor Lægeforen 2002; 122: 1874-9.

10. Molnar FJ, Patel A, Marshall SC et al. Clinical utility of office-based cognitive predictors of fitness to drive in persons with dementia: a systematic review. J Am Geriatr Soc 2006; 54: 1809-24.

11. Reger MA, Welsh RK, Watson GS et al. The relationship between neuropsychological functioning and driving ability in dementia: a meta-analysis. Neuropsychology 2004; 18: 85-93.

12. Mathias JL, Lucas LK. Cognitive predictors of unsafe driving in older drivers: a meta-analysis. Int Psychogeriatrics 2009; 21: 637-53.

13. Ball KK, Roenker DL, Wadley VG et al. Can highrisk older drivers be identified through perfor mance-based measures in a department of motor vehicles setting? J Am Geriatr Soc 2006; 54 $77-84$

14. Laux G. Psychiatric disorders and fitness to drive an automobile. An overview. Nervenarzt 2002; 73 $231-8$.

15. Edlund MJ, Conrad C, Morris P. Accidents among schizophrenic outpatients. Compr Psychiatry 1989 30: $522-6$.

16. De Las Cuevas, Sanz EJ. Fitness to drive of psychiatric patients. Prim Care Companion J Clin Psychiatry 2008; 10: 384-90.

17. Gjerde H, Normann PT, Pettersen BS et al. Prevalence of alcohol and drugs among Norwegian motor vehicle drivers: a roadside survey. Accid Anal Prev 2008; 40: 1765-72

18. Walsh JM, de Gier JJ, Christopherson AS et al. Drugs and driving. Traffic Inj Prev 2004; 5: 241 - 53

19. Asch DA, Jedrziewski K, Christakis A. Response rate to mail surveys published in medical journals. J Clin Epidemiol 1997: 50: 1129-36.

20. Miller DJ, Morley JE. Attitudes of physicans toward elderly drivers and driving policy. J Am Geriatr Soc 1993; 40: $722-4$.

Manuskriptet ble mottatt 26.12. 2009 og godkjent 11.2. 2010. Medisinsk redaktør Petter Gjersvik. 